\title{
BMGlobal Heath Global health governance: we need innovation not renovation
}

\author{
Richard Smith, ${ }^{1}$ Kelley Lee ${ }^{2}$
}

To cite: Smith R, Lee K. Global health governance: we need innovation not renovation. BMJ Global Health 2017;2:e000275. doi:10.1136/bmjgh-2016000275

Received 26 December 2016 Revised 9 February 2017 Accepted 11 February 2017

CrossMark

\footnotetext{
${ }^{1}$ Faculty of Public Health and Policy, London School of Hygiene and Tropical Medicine, London, UK ${ }^{2}$ Faculty of Health Sciences, Simon Fraser University, Burnaby, British Columbia, Canada
}

\section{Correspondence to} Professor Richard Smith; richard.smith@|shtm.ac.uk

\section{INTRODUCTION}

In 1948, my (RS) grandfather bought a car; a Morris Minor. It was slow, cramped and unreliable. Yet, as his needs changed over the years, he did not buy another car because 'it was too difficult' to decide. Today, he does not own a car. He can use community transport, Uber drivers and car sharing schemes. Transport has evolved remarkably since 1948, driven by technological innovation, but also institutional innovation in how we mobilise new technologies. Unlike transport, global health governance has not seen such institutional innovation, even though diseases have globalised and health emergencies become more complex.

Historically, global health governance has rested with the WHO. Criticisms of WHO have become frustratingly familiar-weak internal coordination, cumbersome bureaucracy, political appointments and ineffective leadership. The Ebola outbreak prompted some to describe it as facing a 'do or die' moment. ${ }^{1}$

Despite the Director-General admitting that 'WHO was overwhelmed' ${ }^{2}$ by the outbreak, WHO has not 'done', in the sense of fundamental reform to address criticisms, but nor has it 'died'. Although the global health community widely accepts that WHO is no longer fit-for-purpose, the design and creation of an alternative remain fraught with difficult questions requiring imagination, an agreed vision and political consensus. In their absence, the tinkering continues and, with a few exceptions, ${ }^{3}$ most commentators cling to renovation ('reform'), rather than innovation.

\section{A 'Maginot-line' mentality?}

The United Nations system is designed for a world of 'nation states'. However, globalisation creates new organising logics which reshape human activity and social interaction and erodes territorial boundaries. A world economy dominated by transnational corporations precipitates unprecedented flows

\section{Summary box}

- Although the global health community widely accepts that WHO, as currently configured, is no longer fit-for-purpose, commentators cling to renovation ('reform'), rather than innovation, at the expense of a global health governance system that reflects the needs of a very changed world.

- Collective action in a globalised world requires institutions that look very different from what we currently have. Rather than the renovation of outdated institutional forms-which are closed, territorially fixed and hierarchical-we need to harness innovations such as social networks, open-source systems and the sharing economy.

- One of the biggest forms of institutional innovation more broadly is 'network governance', by which collective action is achieved through interconnected institutions spanning government, business and civil society.

of capital, goods and services worldwide, and the rise of global communications, especially social media, is redefining our identities and perceptions of the world.

In this 'transboundary' world, government institutions based on discrete populations located on fixed territories are increasingly out-of-step. National governments seeking to manage domestic economies, for example, have limited control over factors of production and consumption within a world economy; as the global financial crisis highlighted. Similarly, the capacity of national health systems to protect and promote the health of their citizens is compromised by population mobility.

This erosion of national autonomy coincides with an increased need for collective action to address transboundary risks. Consider disease outbreaks. WHO's capacity to undertake disease surveillance, monitoring and reporting has traditionally relied on reports from member states. The revised International Health Regulations (IHR) extend data collection to non-governmental sources. Nevertheless, information is received 
by WHO and acted on through intergovernmental channels, such as the World Health Assembly and WHO country offices. As the Ebola outbreak highlighted, the system remains vulnerable to limited capacity $(<40 \%$ of member states have implemented the IHR), unwillingness to report outbreaks and lack of enforcement mechanisms. This has prompted calls for further revision, or implementation through alternative channels, such as the Global Health Security Agenda. ${ }^{4}$

There are many salutary lessons about failing to adapt to change. One of the most vivid is the Maginot line. After World War I, the French government developed a system of concrete fortifications, obstacles and weapons installations along its eastern border to slow an enemy invasion and give time for the French army to mobilise. By the 1930s, however, military technology and strategy had moved on and Germany's blitzkrieg tactic, with the rapid use of aircraft and highly mobile forces, overwhelmed French border defences. The country was conquered in just 6 weeks. Seventy years on, amid rapid globalisation, are we guilty of a 'Maginot-line mentality'?

Adaptation to change in health governance can be seen in the emerging ecosystem of innovation to improve health information systems. The Global Public Health Intelligence Network, HealthMap, Google Flu Trends and other 'big' data systems track and predict global disease outbreaks using web-crawling methods. Bluedot, for example, brings together geographic information systems, spatial analytics, data visualisation and computer science to complement expertise in clinical infectious diseases, travel and tropical medicine, and public health to develop new ways of modelling infectious disease spread and impact. Bluedot achieves this by analysing 'big data': 3 billion travellers on commercial flights; mobile human, animal and insect populations; climate data from satellites and news and social media reports of disease outbreaks. Bluedot's innovation is not being reliant on, and therefore constrained by, data provided or organised by country, but envisions the world as a whole, using data configured to capture planetary patterns and trends as the basis for collective action. ${ }^{5}$

\section{Institutional innovation and networked governance}

In business, a distinction is drawn between improvement of existing products and processes, and innovation which is 'something truly different...that makes your customers' lives better. ${ }^{6}$ Innovation thinking has recently been extended to address social issues ('social innovation') and 'institutional innovation', focusing on redesigning the roles, relationships and governance structures required to bring participants together in productive endeavours.

One of the major forms of institutional innovation is 'network governance', where collective action is achieved through interconnected institutions spanning government, business and civil society. Networks aim to create synergies across different competencies and expertise to deal with complex problems, including mobilisation of resources and coproduction of policy interventions. Critically, these networks are fluid, with different actors coming together and then disbanding, to focus on issues of relevance to them. In global health, although public-private partnerships bring together a range of stakeholders like this, critics question how truly 'open' they are, and whether they remain too dominated by powerful state and corporate interests. ${ }^{7-9}$

In contrast, crowdsourcing (obtaining services, ideas or content by soliciting contributions from a large group of people rather than traditional sources) is being used by the Open Source Drug Discovery, launched in 2008, to find solutions for neglected diseases. This brings together around 7500 researchers, students, industries, educational institutions and others across 130 countries to create new drugs in the public domain. ${ }^{10}$ Crowdsourcing is more participatory, iterative and interactive, which can also lead to 'more efficient surfacing of problems'. ${ }^{11}$

There are opportunities for global health governance to draw on such examples of institutional innovation. For instance, the 'sharing economy', whereby people worldwide rent accommodation, vehicles and other major assets directly from each other via online transactions, might help organise how we invest in, and then share, major assets benefiting health across countries, such as laboratories, computer technologies and data sources. Innovations in political institutions and process are also emerging, such as social media analytics and cloud-based policymaking, which seek to open-up policymaking in response to an increasingly complex and fast-paced world. $^{12}$ Existing global health governance institutions have been slow to embrace these new ways of being and doing. Built on traditional public administrative models, they are increasingly obsolete and out-of-step in a transboundary world.

\section{Conclusion: from AIDS to Zika}

Since the 1990s, WHO has undergone almost constant reform under four director generals. All have sought to revive the organisation's leadership role in a world in desperate need of effective global health governance. None have succeeded. Meanwhile, global health has faced a succession of diseases reflecting a globalising world. The AIDS pandemic taught us that global solidarity, not the marginalisation of people living with HIV, is essential to effective prevention, control and treatment. The SARS outbreak and influenza pandemics taught us that all countries-rich or poor-are vulnerable to the rapid global spread of disease. The Ebola outbreak taught us that any weak links in a global system of disease surveillance, monitoring and reporting poses risks to us all. The Zika virus taught us that many diseases are rapidly circulating the planet that pose health risks which we know too little about. All teach us that governments alone are unable to mobilise and deploy sufficient knowledge, human capital and other resources in a timely manner. 
Rather than renovation of outmoded institutional forms-which are closed, territorially fixed and hierarchical-we need to harness the power of networks, open systems and other innovations that enable new forms of collective action to achieve public goals. Human societies are rapidly evolving on a planetary scale. Many argue that WHO was once the lead organisation and can be again. Others ask, if not then what is the alternative? ${ }^{13}$

WHO could potentially regain its leadership role by embracing innovations that share ideas, resources and authority more openly. But this will require it to enable consensus on issues that transcend borders in a nimble and timely manner. ${ }^{14}$ The real innovation, however, will be in mechanisms to facilitate the formation of networks, sharing of resources, generation of ideas and enabling of decision-making across constituencies that are not confined to states alone. The world now needs institutions that bring together expertise and ideas from far and wide, not fixed, bureaucratic and hierarchical structures which constrain how we define problems and their solutions. No matter how much renovation is undertaken, a car from 1948 will never meet modern expectations. Like my grandfather today, we should reflect on our needs, look at the options and be prepared for a stark departure from how we have operated thus far.

Handling editor Seye Abimbola.

Collaborators Kelley Lee.

Competing interests None declared.

Provenance and peer review Not commissioned; externally peer reviewed.
Open Access This is an Open Access article distributed in accordance with the Creative Commons Attribution Non Commercial (CC BY-NC 4.0) license, which permits others to distribute, remix, adapt, build upon this work noncommercially, and license their derivative works on different terms, provided the original work is properly cited and the use is non-commercial. See: http:// creativecommons.org/licenses/by-nc/4.0/

\section{REFERENCES}

1. Moon S, Sridhar D, Pate M, et al. Will Ebola change the game?: Ten essential reforms before the next pandemic. The report of the Harvard-LSHTM Independent Panel on the Global Response to Ebola. Lancet 2015;386:2204-21.

2. Chan M. WHO Director-General's speech at the Sixty-eighth World Health Assembly, Geneva, May. 2015. http://www.who.int/dg/ speeches/2015/68th-wha/en/.

3. Mackey TK. The Ebola outbreak: catalyzing a 'shift' in global health governance? BMC Infect Dis 2016;16:699.

4. Katz R, Dowell SF. Revising the International Health Regulations: call for a 2017 review conference. Lancet Glob Health 2016;3: e352-3.

5. Bluedot. About. http://bluedot.global/ (accessed 8 Feb 2017).

6. Gehring T, Faude B. A theory of emerging order within institutional complexes: how competition among regulatory international institutions leads to institutional adaptation and divisions of labour. Rev Int Organ 2014;9:471-98.

7. Buse K, Harmer A. Power to the partners?: the politics of publicprivate partnerships. Development 2004;47: 49-56.

8. Chan J. Politics in the corridor of dying, AIDS activism and global health governance. Baltimore: Johns Hopkins University, 2015.

9. Hall D. Why public private partnerships don't work. London: Public Services International Research Unit, University of Greenwich, 2015.

10. Open Source Drug Development. About Us. http://www.osdd.net/ about-us (accessed 7 Feb 2017).

11. Shaywitz D. Do something really innovative in health: crowdsource problems, not (just) solutions. Forbes, 3 February 2012.

12. Sørensen E. Political innovations: innovations in political institutions, processes and outputs. J Public Manage Rev 2017;19:1-19.

13. Hoffman SJ, Røttingen JA. Split WHO in two: strengthening political decision-making and securing independent scientific advice. Public Health 2014;128:188-94.

14. Orsini A, Morin JF, Young O. Regime complexes, a buzz, a boom or a boost for global governance? Global Governance 2013;19:27-39. 